Agroradix Vol. 3 No.2

ISSN : 2621-0665

\title{
APLIKASI PLANT GROWTH PROMOTING RHIZOBACTERIA (PGPR) TERHADAP INFEKSI Chrysanthemum mild mottle virus (CMMV), PERTUMBUHAN, DAN PRODUKSI TANAMAN KRISAN (Chrysanthemum sp.)
}

\author{
Fery Abdul Choliq, Mintarto Martosudiro, Safira Candra Jalaweni \\ Jurusan Hama dan Penyakit Tumbuhan Fakultas Pertanian Universitas Brawijaya \\ Email: feryac@ub.ac.id
}

\begin{abstract}
ABSTRAK
Krisan (Chrysanthemum sp.) adalah tanaman florikultura yang memiliki nilai ekonomi tinggi dan berpotensi besar untuk dikembangkan. Budidaya krisan tidak lepas dari kendala penyakit yang menyebabkan penurunan produksi salah satunya adalah serangan penyakit Chrysanthemum mild mottle virus (CMMV) yang menyebabkan gejala rusaknya bunga, tanaman kerdil, dan malformasi. Pengendalian CMMV masih menggunakan insektisida yang bertujuan untuk menekan populasi serangga vektor. Pengurangan penggunaan insektisida dapat menggunakan alternatif pengendalian yang lebih aman yaitu Plant Growth Promoting Rhizobacteria (PGPR). Bacillus subtilis, Pseudomonas fluorescens, dan Azotobacter sp. merupakan rizobakteri yang biasa digunakan sebagai PGPR karena memiliki peranan yang penting dalam mengendalikan serangan patogen dan bermanfaat untuk memacu pertumbuhan dan produksi tanaman. Tujuan dari penelitian ini adalah untuk mengetahui pengaruh pemberian PGPR isolat B. subtilis, P. fluorescens, Azotobacter sp., dan kombinasinya terhadap serangan $\mathrm{CMMV}$, pertumbuhan, dan produksi pada tanaman krisan.

Rancangan penelitian menggunakan Rancangan Acak Lengkap (RAL) 9 perlakuan. $\mathrm{PO}_{+}$: Kontrol positif (tanpa pemberian PGPR, dengan inokulasi virus); PO.: Kontrol negatif (tanpa pemberian PGPR, tanpa inokulasi virus); P1: Inokulasi virus + PGPR isolat $B$. subtilis; P2: Inokulasi virus + PGPR isolat $P$. fluorescens; P3: Inokulasi virus + PGPR isolat Azotobacter sp.; P4: Inokulasi virus + PGPR isolat $B$. subtilis + P. fluorescens; P5: Inokulasi virus + PGPR isolat $B$. subtilis + Azotobacter sp.; P6: Inokulasi virus + PGPR isolat P. fluorescens + Azotobacter; P7: Inokulasi virus + PGPR isolat $P$. fluorescens $+B$. subtilis + Azotobacter sp. Berdasarkan hasil penelitian, diketahui bahwa tanaman krisan yang diberi perlakuan PGPR tiga kombinasi yaitu $P$. fluorescens $+B$. subtilis + Azotobacter sp. menunjukkan hasil yang berbeda nyata dengan perlakuan yang lain. Setelah dikombinasikan, $P$. fluorescens $+B$. subtilis + Azotobacter sp. mampu memberikan hasil terbaik dalam hal menunda masa inkubasi CMMV, menekan intensitas serangan CMMV, serta meningkatkan pertumbuhan dan produksi tanaman krisan.
\end{abstract}

Kata kunci : PGPR, Chrysanthemum, Chrysanthemum mild mottle virus, krisan

\section{ABSTRACT}

Chrysanthemum (Chrysanthemum sp.) is floriculture commodity with high economic value and has great potential to be developed. Chrysanthemum cultivation can not be separated from pests and diseases, one of them is Chrysanthemum mild mottle virus (CMMV). Virus can caused a broken flowers, dwarf, and malformation. CMMV control is still focused on vector control. Necessary efforts to reduce impact of insecticide. The control effort that are currently being developed is a Plant Growth Promoting Rhizobacteria (PGPR). Bacillus subtilis, Pseudomonas fluorescens, and Azotobacter sp. used as PGPR because it has an important role in controlling pathogens, spur growth, and production. The purpose of the research is to know the effect of PGPR isolates of $B$. subtilis, $P$. fluorescens, Azotobacter sp., and the combinations against incubation period, intensity of the attacks CMMV, growth, and production of the chrysanthemum plant. 
Agroradix Vol. 3 No.2

ISSN : 2621-0665

The research design using a completely randomized design (RAL) 9 treatments.PO+ ${ }_{+}$Positive Control (without the granting of PGPR, with the inoculation of the virus); PO-: Negative Control (without the granting of PGPR, without inoculation of the virus); $\mathrm{P} 1: \mathrm{CMMV}+B$. subtilis; $\mathrm{P} 2: \mathrm{CMMV}+$ P. fluorescens; P3: CMMV +Azotobacter sp.; P4: CMMV + B. subtilis + P. fluorescens; P5: CMMV + B. subtilis + Azotobacter sp.; P6: CMMV + P. fluorescens + Azotobacter sp.; P7: CMMV + P. fluorescens + B. subtilis + Azotobacter sp. Based on this research, it is known that chrysanthemum treated with PGPR three combinations ( $P$. fluorescens $+B$. subtilis + Azotobacter sp.) showed significantly different results with other treatments.After combined, capable of providing the best results in terms of delaying the incubation period, pressing attacks of CMMV, as well as the growth and production of chrysanthemum.

Keywords : PGPR, Chrysanthemum, Chrysanthemum mild mottle virus, krisan.

\section{PENDAHULUAN}

Krisan (Chrysanthemum sp.) adalah tanaman florikultura yang memiliki nilai ekonomi tinggi dan berpotensi besar untuk dikembangkan. Tanaman krisan memiliki bentuk dan tipe yang beragam. Selain itu warna bunganya pun sangat bervariasi dengan kombinasi warna yang indah. Krisan juga memiliki berbagai manfaat diantaranya selain sebagai tanaman hias juga ada yang memanfaatkan sebagai campuran obat tradisional serta ada pula yang mengkonsumsinya dalam bentuk teh krisan. Hal tersebut menyebabkan permintaan konsumen terhadap komoditas ini cukup tinggi. Proyeksi permintaan krisan tahun 2014-2019 diperkirakan terus meningkat sampai dengan tahun 2019 hingga mencapai 70.676 ton, dengan rata-rata peningkatan permintaan $12,40 \%$ per tahun (Ekanantari, 2014).

Budidaya krisan tidak lepas dari kendala penyakit salah satunya adalah penyakit yang disebabkan oleh Chrysanthemum mild mottle virus (CMMV) atau lebih dikenal dengan Tomato Aspermy Virus (TAV) (Hammod dan Kaper, 1986). Virus ini telah tersebar pada pertanaman krisan di seluruh dunia. Infeksi virus ini pada tanaman krisan menyebabkan gejala rusaknya bunga, tanaman kerdil, dan malformasi. Kejadian CMMV di dunia terutama di Indonesia masih belum mendapatkan perhatian. Pengetahuan petani terhadap penyakit ini masih kurang padahal serangan CMMV dapat menurunkan produksi yang sangat merugikan produsen. Mengingat krisan merupakan salah satu tanaman hias yang tidak menolelir kerusakan sedikitpun terhadap tanaman karena dapat menurunkan minat konsumen dan nilai jual dari tanaman krisan, maka seharusnya pengendalian OPT (Organisme Pengganggu Tanaman) khususnya penyakit CMMV harus lebih diperhatikan.

Petani krisan masih menggunakan insektisida yang bertujuan untuk menekan populasi serangga vector yaitu Myzus persicae. Kennedy dkk., (1962) menjelaskan bahwa CMMV dapat ditularkan secara non persisten oleh kutu daun Myzus persicae dan beberapa spesies aphididae. Penggunaan insektisida secara berlebihan tentunya akan menyebabkan resistensi hama. Resistensi atau ketahanan hama terhadap pestisida merupakan masalah penting yang harus dihadapi oleh petani. Suatu organisme pengganggu tumbuhan (OPT) disebut resisten jika OPT di suatu daerah menjadi tahan terhadap pestisida yang diberikan sehingga pestisida tersebut tidak efektif untuk menekan keberadaan hama.

Dampak resistensi OPT terhadap pestisida secara ekonomi dan sosial sangat besar. Petani harus mengeluarkan biaya pengendalian lebih besar, karena mereka terpaksa menggunakan dosis yang lebih tinggi atau membeli pestisida baru yang lebih mahal. Resistensi hama tersebut merupakan dampak dari perilaku petani dalam mengaplikasikan pestisida yang tanpa dilandasi oleh pengetahun tentang sifat dasar pestisida dan OPT sasaran. Oleh karena itu perlu dilakukan pengurangan terhadap penggunaan pestisida dalam menekan keberadaan OPT. 
Agroradix Vol. 3 No.2

ISSN : 2621-0665

Alternatif pengendalian yang dapat diterapkan adalah pengendalian yang berdasarkan pada konsep Pengendalian Hama Terpadu (PHT) karena konsep ini bertujuan untuk meminimalisir penggunaan pestisida dan tetap menyelamatkan kehilangan hasil tanaman budidaya terhadap serangan OPT. Konsep PHT bukanlah memberantas, membasmi secara brutal dengan pestisida, atau memusnahkan hama, akan tetapi dilakukan dengan pengontrolan teratur dan rutin, sehingga bila terdapat sesuatu pada tanaman tersebut dapat dilakukan tindakan yang sesuai dengan kondisi hama penyakit yang menyerang.

Salah satu pengendalian yang termasuk komponen dalam konsep PHT adalah pengendalian ramah lingkungan yang didasarkan pada informasi dan pengalaman status OPT pada waktu sebelumnya serta bertujuan untuk mengupayakan agroekosistem yang toleran terhadap OPT. Strategi operasional semacam ini lebih dikenal dengan strategi preemtif (Untung, 1993). Pengendalian dengan strategi preemtif dapat diterapkan dengan memanfaatkan agens hayati. Mikroorganisme yang sudah banyak dilaporkan mampu sebagai agens hayati adalah rizobakteria. Mekanisme pengendalian patogen oleh rizobakteria dapat secara langsung yaitu dengan cara berkompetisi, menghasilkan antibiotik, menghasilkan enzim kitinase, dan menyebabkan lisis pada dinding hifa pathogen seta dapat pula dengan cara tidak langsung (induksi ketahanan dan meningkatkan pertumbuhan tanaman) (Habazar dan Yaherwandi, 2006). Salah satu diantaranya adalah Plant Growth Promotimh Rhizobacteria (PGPR).

Secara umum, fungsi PGPR dalam meningkatkan pertumbuhan tanaman dibagi dalam tiga kategori yaitu : (1) sebagai pemacu atau perangsang pertumbuhan (biostimulan) dengan mensintesis dan mengatur konsentrasi berbagai zat pengatur tumbuh (fitohormon) seperti IAA, giberelin, sitokinin dan etilen dalam lingkungan akar; (2) sebagai penyedia hara (biofertilizer) dengan menambat $\mathrm{N}_{2}$ dari udara, melarutkan hara $\mathrm{P}$ yang terikat di dalam tanah, mengoksidasi sulfur, memobilisasi kalium dan pengkhelatan ion besi; (3) sebagai pengendali patogen berasal dari tanah (bioprotektan) dengan cara menghasilkan berbagai senyawa atau metabolit anti patoogen seperti siderophore, $\beta$-1,3-glukanase, kitinase, antibiotik dan sianida (Millan, 2007).

Terdapat beberapa rhizobacteria yang berperan sebagai PGPR. Beberapa genus yang termasuk dalam PGPR tersebut adalah Pseudomonas, Serratia, Azotobacter, Azospirillum, Acetobacter, Burkholderia, Enterobacter, Rhizobium, Erwinia, Flavobacterium dan Bacillus (Husen dkk., 2006). Masing-masing isolat rhizobacteria memiliki peranan yang penting dalam mengendalikan serangan patogen dan memicu pertumbuhan.

Isolat Bacillussubtilis dilaporkan mampu mensintesis asam indol asetat (IAA) dan giberelin (Salamiah dan Wahdah, 2015). Fungsi hormon IAA bagi tanaman antara lain meningkatkan perkembangan sel, merangsang pembentukan akar baru, memacu pertumbuhan, merangsang pembungaan dan meningkatkan aktivitas enzim (Rahni, 2012). Sedangkan, isolat Pseudomomas fluorescens selain menghasilkan IAA juga menghasilkan sitokinin (Salamiah dan Wahdah, 2015). Selain itu juga terdapat Azotobacter yang mampu meningkatkan ketersediaan nitrogen dalam tanah (Nurmas, 2014). Berdasarkan hal tersebut, perlu dilakukan uji kemampuan isolat rizhobacteria yaitu Bacillus subtilis, Pseudomomas fluorescens, dan Azotobacter sp. sebagai PGPR dalam mengendalikan intensitas serangan CMMV, serta pertumbuhan, dan produksi pada tanaman krisan.

\section{METODE PENELITIAN}

\section{Tempat dan Waktu}

Penelitian dilaksanakan di Laboratorium Penyakit, Jurusan Hama dan Penyakit Tumbuhan, Fakultas Pertanian, Universitas Brawijaya, Malang dan rumah kawat Universitas Widyagama Malang. Pelaksanaan penelitian dimulai pada bulan Juni 2016 sampai dengan September 2016. 
Agroradix Vol. 3 No.2

ISSN : 2621-0665

\section{Alat dan Bahan}

Alat-alat yang digunakan pada penelitian di lapang adalah cangkul, sekop, cetok, meteran, gunting, jangka sorong, kertas label, plastik, tali rafia, gembor, sprayer, alat tulis dan kamera. Alat yang digunakan untuk penelitian di laboratorium adalah cawan petri, lampu ultra violet, timbangan analitik, pipet, gelas ukur, autoclave, laminar air flow cabinet (LAFC), microwave, botol media $250 \mathrm{ml}$, stik $L$, bunsen, korek, plastik, plastik wrapping, kertas saring, sprayer, gunting, alumunium foil, kapas, tisu steril, mortar dan penumbuk, gelas ukur (vol. $100 \mathrm{ml}$ ), dan label.

Bahan yang digunakan yaitu inokulum CMMV yang menginfeksi tanaman krisan di lapang. Bahan tanam yang digunakan berupa stek tanaman yang berasal dari pucuk tanaman krisan yang sehat jenis standar varietas Cocobeach. Tanaman indikator yang digunakan adalah Chenopodium amaranthicolor. Cocopeat dan sekam yang sudah disterilisasi dengan formalin $5 \%$ sebagai media tanam, kompos, ZA, NPK, fungisida b.a Propineb, karborundum 600 mesh, aquades steril, dan buffer fosfat $0,01 \mathrm{M} \mathrm{pH} \mathrm{7,} \mathrm{PGPR}$ isolat $B$. subtilis, Pseudomomas fluorescens, dan Azotobacter sp. dalam bentuk cair dengan kerapatan $10^{8}$ yang diproduksi oleh jurusan hama dan penyakit tumbuhan (HPT), Fakultas Pertanian, Universitas Brawijaya, aquades, alkohol, spirtus, klorok, dan sabun cair. Serta media biakan bakteri King's $B$ yang merupakan media selektif untuk pertumbuhan bakteri $P$. fluorescens, Ashby yang merupakan media selektif untuk pertumbuhan bakteri Azotobacter sp., dan media Nutrient Agar (NA) sebagai media pertumbuhan Bacilus subtilis.

\section{Rancangan Penelitian}

Penelitian ini menggunakan Rancangan Acak Lengkap (RAL) 9 perlakuan (Tabel 1) dengan 3 ulangan sehingga diperoleh 27 tanaman. Perlakuan tersebut adalah $\mathrm{PO}_{+}$: Kontrol positif (tanpa pemberian PGPR, dengan inokulasi virus); PO.: Kontrol negatif (tanpa pemberian PGPR, tanpa inokulasi virus); P1: Inokulasi virus + PGPR isolat $B$. subtilis; $\mathrm{P2}$ : Inokulasi virus + PGPR isolat $P$. fluorescens; P3: Inokulasi virus +
PGPR isolat Azotobacter sp.; P4: Inokulasi virus + PGPR isolat $B$. subtilis + P. fluorescens; P5: Inokulasi virus + PGPR isolat $B$. subtilis + Azotobacter sp.; P6: Inokulasi virus + PGPR isolat $\quad P$. fluorescens + Azotobacter; P7: Inokulasi virus + PGPR isolat $P$. fluorescens + B. subtilis + Azotobacter sp.

\section{Persiapan Penelitian}

\section{Penyediaan Inokulum dan Identifikasi Virus}

Inokulum CMMV berasal dari lokasi ditemukannya tanaman yang terinfeksi CMMV yaitu di Desa Bumiaji, Batu. Tanaman yang terserang CMMV dicirikan dengan adanya gejala serangan seperti mottle atau belang pada daun, malformasi pada daun, serta kerusakan pada bunga. Inokulum yang digunakan yaitu daun tanaman krisan yang menunjukkan gejala belang atau mottle. Sebelum penelitian, dilakukan identifikasi virus $\mathrm{CMMV}$ dengan menggunakan tanaman indikator. Tanaman indikator yang digunakan untuk identifikasi vurus CMMV adalah Chenopodium amaranthicolor. Identifikasi virus pada tanaman indikator dilakukan dengan cara diinokulasi mekanis. Virus tersebut akan menunjukkan gejala serangan CMMV pada C.amaranthicolor yaitu lesio lokal klorotik atau nekrotik tanpa gejala sistemik.

\section{Persiapan Media Tanam}

Media yang digunakan adalah sekam sebagai media persemaian serta campuran cocopeat dan kompos yang digunakan untuk media tanam. Cara sterilisasi media yaitu pertama media disiram menggunakan formalin 5\% dengan konsentrasi $5 \mathrm{cc} /$ liter air secara merata. Tujuannya adalah untuk membersihkan media tanam dari mikroorganisme yang dapat merugikan tanaman. Setelah cairan formalin merata pada media tanam selanjutnya media ditutup dengan plastik selama 7 hari dan dibolak-balik selama 3 hari kemudian media dikeringanginkan selama 7 hari atau sampai formalin tidak berbau. Media yang sudah siap digunakan kemudian dipindahkan ke wadah persemaian dan polybag. Pemilihan media tanam ini mempertimbangkan sifat fisik media yaitu harus ringan, gembur, dan memiliki aerasi yang cukup baik. Adriani 
Agroradix Vol. 3 No.2

ISSN : 2621-0665

(2015) menjelaskan bahwa, kebanyakan krisan ditanam dengan media tanpa tanah. Media krisan yang baik harus dapat memegang air, mempunyai drainase yang baik dan bersih atau bebas dari hama, penyakit, dan gulma. Media tanam yang padat dan berdrainase buruk tidak dapat memberikan kondisi pertumbuhan akar yang optimal. Perbandingan media tanam yang digunakan adalah 4 : 1 dengan komposisi cocopeat dan kompos.

\section{Pembibitan Tanaman Krisan}

Tanaman krisan diperbanyak dengan bahan tanam dari stek pucuk. Bahan tanam berupa stek pucuk disemaikan dalam media persemaian menggunakan media arang sekam. Kemudian setelah tanaman sudah berusia 14 hari setelah semai (HSS), bibit siap dipindahkan pada polybag yang berukuran 30 $x 30 \mathrm{~cm}$. Bibit krisan siap dipindahkan apabila sudah muncul akar.

\section{Perbanyakan Inokulum CMMV}

CMMV diperbanyak pada tanaman krisan varietas Cocobeach dengan cara menginokulasikannya secara mekasnis. Inokulasi dilakukan setelah tanaman berumur \pm 14 hst. Sap yang mengandung CMMV diinokulasikan pada daun muda yang telah membuka sempurna. Kemudian daun krisan yang menunjukkan gejala diambil dan diawetkan dengan cara disimpan dalam botol kaca $(100 \mathrm{ml})$ yang sebelumnya sudah diisi dengan $\mathrm{CaCl}_{2}$. Penggunaan $\mathrm{CaCl}_{2}$ berfungsi sebagai bahan pengering atau desikator pada daun yang bergejala.

\section{Penyediaan Bakteri PGPR}

Isolat bakteri PGPR yang didapatkan berasal dari koleksi Laboratorium Penyakit, Jurusan Hama dan Penyakit Tumbuhan Universitas Brawijaya Malang. Bakteri yang digunakan yaitu Bacillus subtilis, Pseudomonas fluorescens dan Azotobacter sp. dalam bentuk cair dengan kerapatan $10^{8}$ yang diproduksi oleh jurusan Hama dan Penyakit Tumbuhan, Fakultas Pertanian, Universitas Brawijaya.

\section{Pelaksanaan Penelitian}

\section{Aplikasi PGPR}

Bibit tanaman krisan yang sudah berusia 14 HSS selanjutnya dipindahkan ke polybag untuk ditanam. Bibit dicabut dari media semai lalu akar dicuci dengan aquades. Akar yang sudah bersih dari media semai kemudian direndam di PGPR selama 10 menit. Konsentrasi larutan yang digunakan untuk merendam adalah $10 \mathrm{ml}$ PGPR/liter air. Terdapat 21 pot yang diberi perlakuan PGPR sedangkan 6 tanaman sebagai kontrol tanpa diberi perlakuan PGPR.

\section{Penanaman}

Media tanam yang sudah disiapkan dan telah disterilkan dimasukkan dalam polybag berukuran $30 \times 30$ berjumlah 27 buah. Pengisian tanah sejumlah $4 / 5$ bagian dari tinggi polybag. Bibit krisan yang sudah tumbuh normal pada persemaian kemudian dipindahkan pada polybag.

\section{Inokulasi CMMV pada Tanaman Krisan}

Penularan inokulum CMMV pada tanaman krisan dilakukan secara mekanis menggunakan sap. CMMV diinokulasikan pada tanaman krisan saat berumur 7 hari setelah tanam (HST). Inokulasi dilakukan pada daun muda yang telah membuka sempurna. Tanaman krisan dilukai secara mekanis menggunakan karborundum 600 mesh pada bagian permukaan daun kemudian sap CMMV dioleskan menggunakan tangan pada permukaan daun yang telah dilukai. Daun yang telah diinokulasi dibiarkan dua menit, kemudian dibilas dengan air dengan kapas atau tisu bersih. Pembilasan setelah perlakuan inokulasi ini dimaksudkan untuk menghilangkan sisa karborundum yang masih menempel pada bagian permukaan daun.

\section{Pemeliharaan Tanaman Krisan}

Pemeliharaan tanaman uji meliputi penyiraman, pemberian hari panjang atau penyinaran, pemangkasan pucuk atau pinching, pemupukan, pemasangan tali penyangga atau ajir, penyiangan gulma, dan pengendalian hama penyakit tanaman. Penyiraman dilakukan setiap dua hari sekali atau jika kondisi media tanam pada polybag 
Agroradix Vol. 3 No.2

ISSN : 2621-0665

kering. Pemberian hari panjang atau penyinaran diberikan sejak awal tanam hingga 21 hst. Setelah 1 minggu pemberian hari panjang dilakukan pemangkasan pucuk yang bertujuan untuk memperbanyak tunas.

Pemupukan dilakukan setiap 1 minggu sekali sejak stek dipindah ke polybag hingga 2 minggu sebelum panen. Pupuk yang digunakan adalah urea dengan konsentrasi 2 g/l. Pemasangan tali penyangga atau ajir dilakukan pada saat tanaman berumur 21 HST. Tujuannya adalah untuk mempertahankan kondisi tanaman agar tidak rebah. Tali penyangga yang digunakan bisa dengan tali rafia yang diikatkan pada kawat. Sanitasi gulma dilakukan secara manual dengan melakukan pencabutan jika terdapat gulma yang dapat mengganggu pertumbuhan dan perkembangan dari tanaman penelitian. Pengedalian OPT juga dilakukan secara manual dengan mengambil hama dan diletakkan pada botol air mineral agar tidak menyerang pada tanaman uji, sedang jika terdapat tanda tanaman terserang oleh patogen lain selain virus dilakukan perompesan bagian tanaman yang terserang.

\section{Variabel Pengamatan}

Variabel pengamatan dalam penelitian ini meliputi masa inkubasi serta kenampakan gejala CMMV, intensitas serangan, pertumbuhan tanaman (tinggi tanaman dan jumlah daun), dan produksi tanaman (waktu munculnya primordia bunga, jumlah bunga total, dan diameter bunga).

\section{Masa Inkubasi dan Kenampakan Gejala}

Masa inkubasi adalah periode waktu dari inokulasi sampai munculnya gejala pada tanaman krisan. Pengamatan masa inkubasi dihitung mulai dari satu hari setelah inokulasi sampai dengan munculnya gejala pertama pada semua perlakuan dalam satuan hari. Kenampakkan gejala yang diamati meliputi perubahan bentuk dan warna daun yang diinokulasikan CMMV.

Intensitas serangan

Pengamatan intensitas serangan penyakit pada tanaman krisan yang terinfeksi CMMV, terlebih dahulu dilakukan dengan cara menentukan skala kerusakan. Kerusakan yang terjadi akibat serangan penyakit dapat dilihat dari kondisi fisik tanaman seperti daun, bunga, dan kondisi tanaman tanaman sesuai dengan gejala penyakit CMMV. Rumus untuk menghitung intensitas serangan CMMV pada tanaman uji dan skor tiap kategori serangan (Tabel 1) ditentukan menurut metode Zubaidah dkk (2006) dalam Suryanto, dkk. (2015) yaitu:

Keterangan:

$$
\mathrm{I}=\frac{\sum(\mathrm{nxv})}{\mathrm{NxV}} \times 100 \%
$$

I : intensitas serangan tiap tanaman

$\mathrm{n}$ : jumlah daun dari setiap kategori serangan

$\checkmark$ : nilai skor dari setiap kategori serangan

$\mathrm{N}$ : jumlah daun yang diamati tiap tanaman

$\mathrm{V}$ : nilai skor dari kategori serangan tertinggi

Tabel 1. Skoring Serangan CMMV pada Daun Tanaman Krisan

\begin{tabular}{lc}
\multicolumn{1}{c}{ Gejala Serangan } & Skor \\
\hline Tanaman sehat tanpa gejala infeksi & 0 \\
Tanaman tampak sehat namun terdapat sedikit mottle, tetapi tidak jelas & 1 \\
Tampak mottle dan tidak berkerut & 2 \\
Tampak mottle, sedikit berkerut, sedikit mosaik & 3 \\
Tampak mottle, berkerut, mosaik & 4 \\
Tampak mottle, berkerut, mosaik, nekrosis pada permukaan dan bagian bawah daun, & 5 \\
malformasi, daun kerdil, melengkung ke bawah atau ke atas & 5 \\
\hline
\end{tabular}

\section{Pertumbuhan dan Produksi Tanaman Krisan} Pengamatan pertumbuhan tanaman krisan dilakukan pada 7, 14, 21, 28, 35 HST. Adapun indikator pertumbuhan tanaman krisan yang diamati sebagai variabel perngamatan adalah tinggi tanaman, jumlah daun, waktu munculnya primordia bunga, jumlah bunga total dan diameter bunga. 
Agroradix Vol. 3 No.2

ISSN : 2621-0665

\section{Analisis Data}

Analisis sidik ragam atau Analysis of Variance (ANOVA) pada data hasil penelitian mengenai masa inkubasi CMMV, intensitas serangan CMMV pada tanaman krisan, pertumbuhan dan produksi tanaman krisan dilakukan dengan menggunakan uji F. Aplikasi yang digunakan adalah perangkat lunak excel dan DSAASTAT ver. 1.101. Masing-masing F hitung dibandingkan dengan $F$ tabel pada level nyata 5\%. Apabila $\mathrm{F}$ hitung < $\mathrm{F}$ tabel $5 \%$ berarti perlakuan tersebut tidak berpengaruh nyata terhadap variabel yang diamati. Jika $\mathrm{F}$ hitung > F tabel $5 \%$ berarti perlakuan berpengaruh nyata terhadap variabel yang diamati. Apabila data yang dianalisis berbeda nyata, maka akan diuji lanjut menggunakan uji lanjut Duncan Multiple Range Test (DMRT) taraf 5\%.

\section{HASIL DAN PEMBAHASAN}

\section{Pengaruh PGPR terhadap Masa Inkubasi CMMV pada Tanaman Krisan}

Masa inkubasi virus merupakan tenggang waktu antara masuknya virus sampai tampaknya gejala. Masa Inkubasi tanaman krisan (Tabel 1) pada pengamatan di lapang memiliki masa yang berbeda mulai dari 3 hari hingga 11 hari setelah masa inokulasi. Berdasarkan analisis ragam mengenai pengaruh PGPR terhadap masa inkubasi CMMV pada tanaman krisan di lapang diperoleh hasil yang berbeda nyata.

Masa inkubasi pada perlakuan kontrol cenderung lebih singkat dibandingkan pada tanaman krisan yang diberi perlakuan PGPR baik itu PGPR tunggal maupun kombinasi. Tanaman krisan yang diberi perlakuan PGPR tunggal $B$. subtilis memiliki rerata masa inkubasi selama 6,67 HIS dan nilai tersebut tidak memiliki hasil yang berbeda nyata ketika dibandingkan dengan PGPR tunggal yang lain yaitu $P$. fluorescens $(6,33 \mathrm{HSI})$ dan Azotobacter sp. (7,33 HIS). Nilai ini tidak berbeda nyata dengan perlakuan PGPR isolat $B$. subtilis yang dikombinasikan dengan $P$. fluorescens (7,00 HIS) maupun dengan $B$. subtilis yang dikombinasikan dengan Azotobacter sp $(8,67 \mathrm{HSI})$ namun berbeda nyata dengan $B$. subtilis yang dikombinasikan bersama-sama dengan $P$. fluorescens dan Azotobacter sp $(10,67 \mathrm{HSI})$. Hal ini sesuai dengan hasil penelitian Choliq dkk. (2019) yang menyatakan bahwa masa inkubasi serangan virus pada perlakuan paling cepat jika dibandingkan dengan perlakuan pemberian pupuk hayati.

Perlakuan PGPR P. fluorescens $(6,33$

$\mathrm{HSI})$ menunjukkan hasil yang berbeda nyata ketika dibandingkan dengan PGPR perlakuan tunggal yang lain. $\quad P$. fluorescens yang dikombinasikan dengan Azotobacter sp. $(8,67$ HSI) tidak menunjukkan hasil yang berbeda nyata ketika dibandingkan dengan perlakuan PGPR dua kombinasi $B$. subtilis $+P$. fluorescens. dan PGPR tiga kombinasi $P$. fluorescens $+B$. subtilis + Azotobacter sp.

Perlakuan PGPR Azotobaacter sp. tidak tampak berbeda nyata jika dibandingkan dengan perlakuan PGPR tunggal yang lain. Begitu pula ketika dibandingkan dengan perlakuan PGPR dua kombinasi yaitu $B$. subtilis + Azotobacter sp. $(8,67 \mathrm{HSI})$ dan $P$. fluorescens + Azotobacter sp. (8,67 HSI). Namun akan tampak berbeda nyata ketika dibandingkan dengan perlakuan PGPR tiga kombinasi $P$. fluorescens $+B$. subtilis + Azotobacter sp. 
Agroradix Vol. 3 No.2

ISSN : 2621-0665

Tabel 1. Pengaruh PGPR terhadap Masa Inkubasi CMMV pada Tanaman Krisan

\begin{tabular}{lc}
\multicolumn{1}{c}{ Perlakuan } & Masa Inkubasi (HSI) \\
\hline Kontrol (tanpa PGPR) & $4,33 \mathrm{a}$ \\
B. subtilis & $6,67 \mathrm{bc}$ \\
P. fluorescens & $6,33 \mathrm{~b}$ \\
Azotobacter sp. & $7,33 \mathrm{bc}$ \\
B. subtilis + P. fluorescens & $7,00 \mathrm{bc}$ \\
B. subtilis + Azotobacter sp. & $8,67 \mathrm{~cd}$ \\
P. fluorescens + Azotobacter sp. & $8,67 \mathrm{~cd}$ \\
P. fluorescens + B. subtilis + Azotobacter sp. & $10,67 \mathrm{~d}$ \\
\hline$\quad$ angka yang diikuti dengan huruf yang sama dalam kolom menunjukkan tidak berbeda nyata pada uji
\end{tabular}

Masa inkubasi CMMV pada tanaman krisan yang diamati memiliki kisaran rerata antara 4 hingga 11 hari. CMMV memiliki rentang waktu tertentu untuk melakukan invasi sampai menimbulkan gejala. Hal ini dipengaruhi oleh beberapa faktor internal dan eksternal. Faktor internal merupakan ketahanan tanaman itu sendiri kemudian faktor luar adalah dari pengaruh lingkungan tempat tumbuh tanaman meliputi naungan, suhu dan musim. Menurut Sastrahidayat (2011), mengatakan bahwa penyebaran virus pada tanaman bervariasi bergantung pada jenis virus tersebut, tanaman dan interaksi yang terjadi diantara keduanya. Bos (1990) menambahkan bahwa perbedaan waktu masa inkubasi pada tanaman dipengaruhi pula oleh jenis tanaman dan keberhasilan virus untuk memperbanyak diri atau bermultiplikasi dalam jaringan inang yang berbeda pula, sehingga didapatkan masa inkubasi yang berbeda pula.

\section{Pengaruh PGPR terhadap Intensitas} Serangan CMMV pada Tanaman Krisan

Berdasarkan pengamatan yang telah dilakukan mengenai pengaruh PGPR terhadap intensitas serangan CMMVpada tanaman Tabel 2. Pengaruh PGPR terhadap Intensitas Serangan CMMV pada Tanaman Krisan

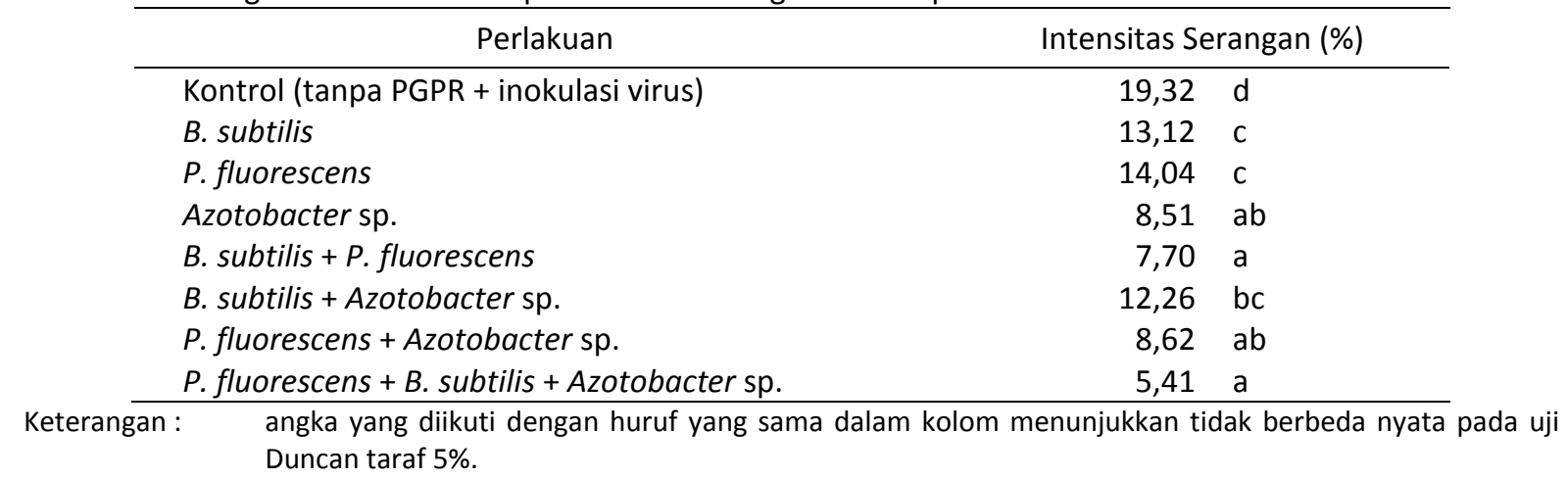

krisan dapat diketahui bahwa persentase intensitas serangan memiliki nilai yang berbeda pada masing-masing perlakuan. Tinggi atau rendahnya intensitas penyakit pada suatu tanaman dapat dipegaruhi oleh beberapa faktor, diantaranya adalah inang, patogen dan lingkungan (Agrios, 2005).

Berdasarkan grafik laju intensitas serangan CMMV diketahui bahwa masingmasing tanaman krisan yang diberi perlakuan PGPR memberikan respon yang berbeda-beda terhadap intensitas serangan CMMV. Tanaman krisan yang menjadi kontrol perlakuan menunjukkan hasil intensitas yang lebih tinggi dibandingkan tanaman krisan yang diberi perlakuan PGPR. Intensitas serangan yang paling rendah tampak pada tanaman krisan yang diberi perlakuan PGPR tiga kombinasi $P$. fluorescens $+B$. subtilis + Azotobacter sp.

Analisis ragam yang dilakukan untuk mengetahui pengaruh PGPR terhadap intensitas serangan CMMV pada tanaman krisan menunjukkan hasil yang berbeda sangat nyata. Hal ini terbukti setelah dilakukan uji lanjut sehingga diperoleh hasil yang tertera pada Tabel 2 . 
Agroradix Vol. 3 No.2

ISSN : 2621-0665

Berdasarkan tabel tersebut diperoleh hasil yang berbeda nyata amtara perlakuan kontrol dengan tanaman yang diberi perlakuan PGPR. Intensitas pada perlakuan kontrol cenderung lebih tinggi dibandingkan dengan intensitas serangan pada tanaman yang diberi perlakuan PGPR (Gambar 1).

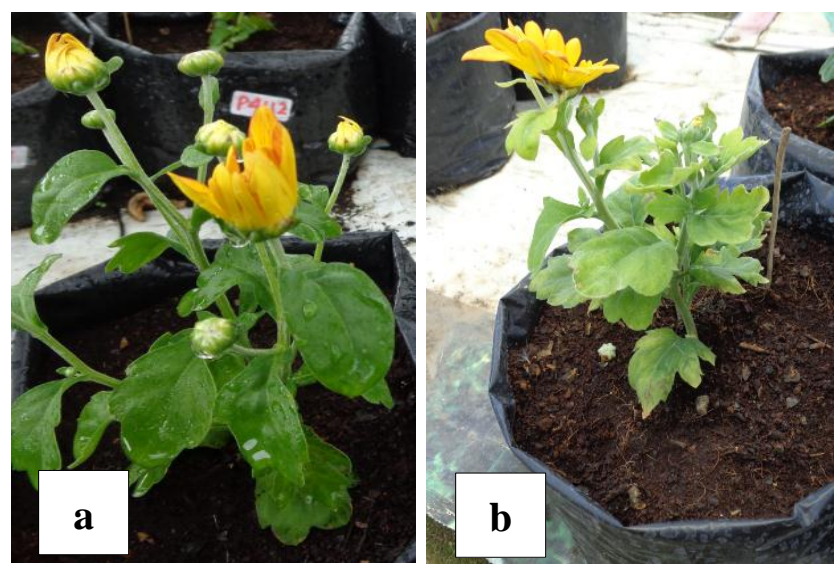

Gambar 1. Perbandingan Intensitas Serangan CMMV. (a. diberi perlakuan PGPR dan b. perlakuan kontrol)

Perlakuan yang diberi perlakuan PGPR tunggal isolat $B$. subtilis tampak tidak berbeda nyata jika dibandingkan dengan PGPR tunggal isolat $P$. fluorescens $(14,04 \%)$ dan tampak berbeda nyata ketika dibandingkan dengan PGPR tunggal isolat Azotobacter sp. (8,51\%). Selanjutnya ketika dibandingkan dengan PGPR isolat $B$. subtilis yang dikombinasikan dengan Azotobacter sp. $(12,26 \%)$ tidak tampak berbeda nyata namun tampak berbeda nyata jika dibandingkan dengan PGPR $B$. subtilis yang dikombinasikan dengan $P$. fluorescens $(7,70 \%)$ dan PGPR tiga kombinasi $P$. fluorescens + B. subtilis + Azotobacter sp. $(5,41 \%)$. Kemudian ketika PGPR B. subtilis yang dikombinasikan dengan $P$. fluorescens dan PGPR tiga kombinasi $P$. fluorescens $+B$. subtilis + Azotobacter sp. dibandingkan tidak menunjukkan hasil yang berbeda nyata.

PGPR isolat tunggal $P$. fluorescens menunjukkan hasil yang berbeda nyata jika dibandingkan dengan PGPR isolat tunggal Azotobacter sp. (8,51\%). Hasil yang berbeda nyata juga tampak pada PGPR dua kombinasi yaitu $P$. fluorescens yang dikombinasikan dengan $B$. subtilis $(7,70 \%)$ maupun kombinasi $P$. fluorescens yang dikombinasikan dengan Azotobacter sp. (8,62\%). Begitu pula ketika dibandingkan dengan PGPR tiga kombinasi $P$. fluorescens $+B$. subtilis + Azotobacter sp. juga menunjukkan hasil yang berbeda nyata.
Namun, ketika PGPR dua kombinasi $B$. subtilis $+P$. fluorescens, $P$. fluorescens + Azotobacter sp., dan PGPR tiga kombinasi P. fluorescens + B. subtilis + Azotobacter sp. dibandingkan justru menunjukkan hasil yang tidak berbeda nyata.

Perlakuan PGPR isolat tunggal Azotobacter sp. tidak menunjukkan hasil yang berbeda nyata jika dibandingkan dengan PGPR Azotobacter sp. yang dikombinasikan dengan $B$. subtilis $(12,26 \%)$ maupun yang dikombinasikan dengan $P$. fluorescens $(8,62 \%)$. Begitu pula ketika dibandingkan dengan PGPR tiga kombinasi $P$. fluorescens + B. subtilis + Azotobacter sp. Namun, ketika PGPR dua kombinasi $B$. subtilis + Azotobacter sp. dibandingkan dengan PGPR tiga kombinasi $P$. fluorescens $+B$. subtilis + Azotobacter sp. menunjukkan hasil yang berbeda nyata.

Hasil yang dipaparkan pada tabel diatas menunjukkan bahwa semua perlakuan PGPR diduga dapat menurunkan intensitas penyakit CMMV pada tanaman krisan. Bakteri antagonis yang dijadikan PGPR dapat menghasilkan senyawa antibiotik atau memiliki kemampuan menghasilkan enzim tertentu yang mampu menekan perkembangan penyakit CMMV. Antibiotik berasal dari kata "anti" yang berarti lawan dan "bios" yang berarti hidup, merupakan senyawa-senyawa kimia yang dihasilkan oleh 
Agroradix Vol. 3 No.2

ISSN : 2621-0665

mikroorganisme terutama jamur dan bakteri yang memiliki sifat mematikan dan menghambat pertumbuhan kuman (mikroorganisme yang merugikan) (Panagan, 2011).

\section{Pengaruh PGPR terhadap Pertumbuhan Tanaman Krisan}

Indikator yang digunakan untuk mengetahui pengaruh perlakuan terhadap pertumbuhan adalah tinggi tanaman dan jumlah daun. Secara umu terlihat perbedaan antara tanaman krisan yang diberi perlakuan PGRP dan kontrol (tanpa pemberian PGPR). Perbandingan perbedaan tersebut dapat dilihat pada Gambar 2.

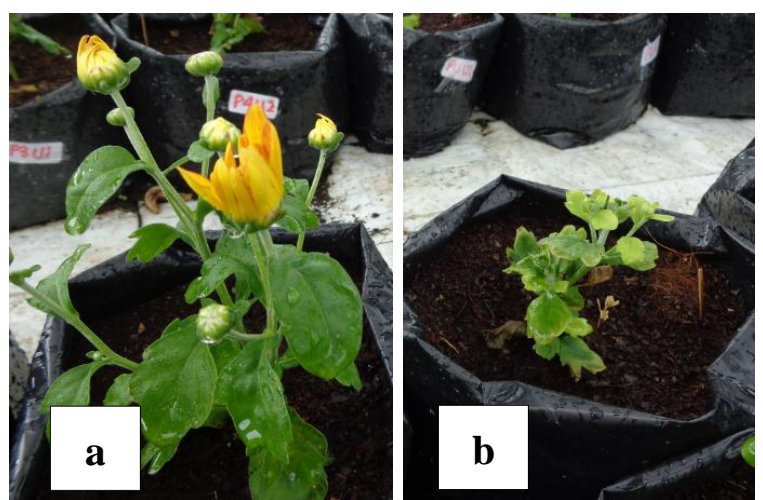

Gambar 2. Perbandingan Kondisi Tanaman Krisan. (a. diberi perlakuan PGPR dan b. perlakuan kontrol)

Tinggi tanaman Pertumbuhan tinggi tanaman krisan selama kurun waktu 35 HST, cenderung mengalami peningkatan. Hal ini dapat dilihat dari data hasil pengamatan tinggi tanaman krisan yang menunjukkan peningkatan tinggi tanaman setiap minggunya baik pada perlakuan kontrol maupun pada tanaman yang diberi perlakuan PGPR. Meskipun tanaman krisan mengalami peningkatan setiap minggu pengamatan, tetapi jumlah peningkatan tinggi tanaman krisan tidak seragam (Tabel 3).

Tabel 3. Pengaruh PGPR terhadap Tinggi Tanaman Krisan

\begin{tabular}{lrl}
\hline \multicolumn{1}{c}{ Perlakuan } & Tinggi Tanaman (cm) \\
\hline Kontrol A (tanpa PGPR + tanpa inokulasi CMMV) & 10,70 ab \\
Kontrol B (tanpa PGPR + inokulasi CMMV) & $6,97 \quad \mathrm{a}$ \\
B. subtilis & $11,33 \mathrm{~b}$ \\
P. fluorescens & $12,23 \mathrm{~b}$ \\
Azotobacter sp. & $13,80 \mathrm{bc}$ \\
B. subtilis + P. fluorescens & $16,53 \mathrm{~cd}$ \\
B. subtilis + Azotobacter sp. & $16,77 \mathrm{~cd}$ \\
P. fluorescens + Azotobacter sp. & $19,07 \mathrm{~d}$ \\
P. fluorescens + B. subtilis + Azotobacter sp. & 25,90 e \\
\hline
\end{tabular}

Keterangan: angka yang diikuti dengan huruf yang sama dalam kolom menunjukkan tidak berbeda nyata pada uji Duncan taraf 5\%

Setelah dilakukan analisis ragam terhadap tinggi tanaman (Tabel 6, Lampiran 3, tabel lampiran 1-5) diketahui bahwa tidak terdapat perbedaan yang nyata antar dua perlakuan kontrol baik pada kontrol A $(10,70$ $\mathrm{cm})$ maupun kontrol $B(6,97 \mathrm{~cm})$. Ketika perlakuan kontrol $\mathrm{B}$ dibandingkan dengan seluruh perlakuan PGPR tampak berbeda nyata. Antar perlakuan PGPR yang menunjukkan hasil berbeda nyata dibandingkan perlakuan PGPR lain adalah PGPR tiga kombinasi $B$. subtilis $+P$. fluorescens + Azotobacter sp. $(25,90 \mathrm{~cm})$. Masing-masing PGPR perlakuan tunggal, ketika dibandingkan tidak menunjukkan hasil yang berbeda secara nyata baik itu PGPR tunggal isolat $B$. subtilis $(11,33 \mathrm{~cm}), P$. 
Agroradix Vol. 3 No.2

ISSN : 2621-0665

florescens $(12,23 \mathrm{~cm})$, maupun Azotobacter sp. $(13,80 \mathrm{~cm})$.

Perlakuan PGPR isolat tunggal $B$. subtilis menunjukkan hasil yang berbeda nyata jika dibandingkan dengan $B$. subtilis yang kombinasikan dengan $P$. fluorescens $(16,53 \mathrm{~cm})$ maupun yang dikombinasikan dengan Azotobacter sp. $(16,77 \mathrm{~cm})$ namun ketika PGPR dua kombinasi $B$. subtilis $+P$. fluorescens dan $B$. subtilis + Azotobacter sp. dibandingkan diperoleh hasil yang tidak berbeda nyata. Kejadian yang hampir sama juga tampak pada PGPR isolat tunggal $P$. fluorescens yang menunjukkan hasil yang berbeda nyata jika dibandingkan dengan $B$. subtilis $(16,53 \mathrm{~cm})$ maupun yang dikombinasikan dengan Azotobacter sp. $(13,80 \mathrm{~cm})$, namun ketika PGPR dua kombinasi $B$. subtilis $+P$. fluorescens dan $P$. fluorescens + Azotobacter sp. dibandingkan, hasil yang diperoleh tidak berbeda nyata.

Perlakuan PGPR tunggalisolat Azotobacter sp. tidak menunjukkan hasil yang berbeda nyata ketika dibandingkan dengan Tabel 4. Pengaruh PGPR terhadap Jumlah Daun Tanaman Krisan

\begin{tabular}{lc}
\multicolumn{1}{c}{ Perlakuan } & Jumlah Daun \\
\hline Kontrol A (tanpa PGPR + tanpa inokulasi CMMV) & 13,33 ab \\
Kontrol B (tanpa PGPR + inokulasi CMMV) & 12,33 a \\
B. subtilis & 20,33 bcd \\
P. fluorescens & 18,33 abc \\
Azotobacter sp. & 17,33 abc \\
B. subtilis + P. fluorescens & $22,00 \mathrm{cde}$ \\
B. subtilis + Azotobacter sp. & $26,00 \mathrm{de}$ \\
$\begin{array}{l}\text { P. fluorescens + Azotobacter sp. } \\
\text { P. fluorescens + B. subtilis + Azotobacter sp. }\end{array}$ \\
Keterangan : angka yang diikuti dengan huruf yang sama dalam kolom menunjukkan tidak berbeda nyata
\end{tabular}

Setelah dilakukan analisa statistik dapat di ketahui bahwa tidak ada pengaruh yang berbeda nyata antara perlakuan kontrol A $(13,33$ helai) maupun perlakuan kontrol B (12,33 helai). Ketika dilakukan perbandingan antara perlaku an kontrol dengan tanaman yang diberi perlakuan PGPR tampak hasil yang berbeda nyata pada keseluruhan perlakuan PGPR kecuali pada perlakuan PGPR tunggal $P$. fluorescens (18,33 helai) dan Azotobacter sp. (17,33 helai).

Perlakuan PGPR tungga $B$. subtilis (20,33 helai) menunjukkan hasil yang tidak
PGPR Azotobacter sp. yang dikombinasikan dengan $B$. subtilis $(16,77 \mathrm{~cm})$ namun menunjukkan hasil yang berbeda nyata ketika dikombinasikan dengan $P$. fluorescens $(19,07$ $\mathrm{cm}$ ). Ketika kedua perlakuan kombinasi tersebut dibandingkan ternyata menunjukkan hasil yang tidak berbeda nyata.

Jumlah daun.

Pengukuran jumlah daun tanaman krisan merupakan bagian dari pengambilan data vegetatif pada tanaman uji untuk mengetahui adanya perubahan pada tanaman setelah tanaman diinokulasikan CMMV. Berdasarkan hasil analisa ragam, diketahui bahwa masing-masing perlakuan memberikan hasil yang beragam untuk jumlah daun. Setelah dilakukan analisa statistik, dapat diketahui jika PGPR berpengaruh nyata terhadap pertumbuhan jumlah daun pada tanaman krisan hal ini terlihat dari jumlah daun pada tanaman perlakuan kontrol berbeda nyata dengan tanaman yang diberi perlakuan PGPR (Tabel 4). berbeda nyata ketika dibandingkan dengan perlakuan PGPR tunggal yang lain seperti $P$. fluorescens dan Azotobacter sp. Selanjutnya ketika dibandingkan dengan $B$. subtilis yang dikombinasikan dengan $P$. fluorescens $(22,00$ helai) dan Azotobacter sp. (26,00 helai) menujukkan hasil yang tidak berbeda nyata pula namun menunjukkan hasil yang berbeda nyata ketika dibandingkan dengan perlakuan tiga kombinasi $P$. fluorescens $+B$. subtilis + Azotobacter sp. (28,33 helai).

Perbandingan selanjutnya dilakukan pada PGPR isolat $P$. fluorescens dengan 
perlakuan PGPR tunggal yang lain dan hasil yang diperoleh tidak berbeda nyata. Hasil yang tidak berbeda nyata juga tampak jika dibandingkan dengan perlakuan $P$. fluorescens yang dikombinasikan dengan $B$. subtillis (22,00 helai). Sedangkan ketika dibandingkan dengan perlakuan $P$. fluorescens yang dikombinasikan dengan Azotobacter sp. (26,00 helai) begitu pula ketika dibandingkan dengan perlakuan tiga kombinasi $P$. fluorescens $+B$. subtilis + Azotobacter sp. Namun, ketika ketiga perlakuan $B$. subtillis yang dikombinasikan baik itu dua kombinasi maupun tiga kombinasi dibandingkan, hasil yang diperoleh adalah tidak berbeda nyata.

Perlakuan PGPR isolat Azotobacter sp. menunjukkan hasil yang tidak berbeda nyata dibandingkan dengan perlakuan PGPR isolat tunggal yang lain. Ketika dibandingkan dengan Azotobacter sp. yang dikombinasikan dengan $B$. subtilis, $P$. fluorescens, maupun yang dikombinasikan menjadi tiga kombinasi $P$. fluorescens $+B$. subtilis + Azotobacter sp. menunjukkan hasil yang berbeda nyata.

\section{Pengaruh PGPR terhadap Produksi Tanaman Krisan}

\section{Waktu muncul primordia bunga}

Berdasarkan analisis ragam mengenai pengaruh PGPR terhadap waktu muncul primordia bunga pertama dapat diketahui bahwa tidak tampak perbedaan yang nyata antara kontrol A (5,33 MST) maupun kontrol B (6,67 MST). Hasil yang tidak berbeda nyata juga tampak pada kontrol $B$ dengan beberapa perlakuan PGPR yaitu PGPR tunggal isolat $B$. subtilis (5,33 MST) dan Azotobacter sp. (5,33 MST). Setelah dilakukan analisa statistik, dapat diketahui pula bahwa hasil dari perbandingan keseluruhan perlakuan PGPR tidak tampak perbedaan yang nyata.

Tabel 5. Pengaruh PGPR terhadap Waktu Muncul Primordia Bunga Pertama

\begin{tabular}{lc}
\multicolumn{1}{c}{ Perlakuan } & $\begin{array}{r}\text { Waktu Muncul Primordia Bunga } \\
\text { Pertama (MST) }\end{array}$ \\
\hline Kontrol A (tanpa PGPR + tanpa inokulasi CMMV) & $5,33 \mathrm{ab}$ \\
Kontrol B (tanpa PGPR + inokulasi CMMV) & $6,67 \mathrm{~b}$ \\
B. subtilis & $5,33 \mathrm{ab}$ \\
P. fluorescens & $5,00 \mathrm{a}$ \\
Azotobacter sp. & $5,33 \mathrm{ab}$ \\
B. subtilis + P. fluorescens & $4,67 \mathrm{a}$ \\
B. subtilis + Azotobacter sp. & $5,00 \mathrm{a}$ \\
P. fluorescens + Azotobacter sp. & $4,00 \mathrm{a}$ \\
P. fluorescens + B. subtilis + Azotobacter sp. & $4,00 \mathrm{a}$ \\
Keterangan :*angka yang diikuti dengan huruf yang sama dalam kolom menunjukkan tidak berbeda nyata pada uji \\
Duncan taraf 5\%. \\
*MST: Minggu Setelah Tanam
\end{tabular}

\section{Jumlah bunga total}

Jumlah bunga dilakukan selama 5 kali pengamatan yaitu sejak tanaman berusia 6 MST tepatnya ketika terdapat bunga yang sudah mekar hingga 10 MST. Berdasarkan hasil pengamatan, diketahui bahwa jumlah bunga pada saat pengamatan pada keseluruhan perlakuan memberikan hasil yang beragam meskipun secara umum jumlah bunga total meningkat. Hanya saja pada perlakuan kontrol terdapat penurunan jumlah bunga total, hal ini dikarenakan terdapat bunga yang gagal membuka sempurna. Tanaman membentuk kuncup tetapi kuncup tersebut tidak bisa membuka sempurna dan justru mati (Gambar 3). 
Agroradix Vol. 3 No.2

ISSN : 2621-0665

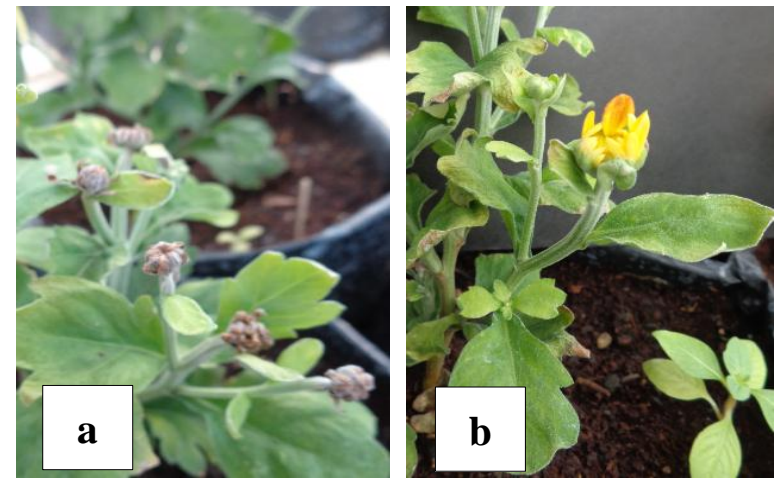

Gambar 3. Kuncup Bunga Tanaman Krisan. (a. kuncup mati dan b. tidak dapat membuka sempurna)

Laju pertambahan jumlah bunga total pada tanaman krisan yang diamati dapat dilihat juga pada grafik (Gambar 4) yang menampilkan hasil tentang pertambahan jumlah bunga dari tanaman krisan. Grafik tersebut menunjukkan bahwa jumlah bunga yang dihasilkan memiliki keterkaitan dengan perlakuan PGPR yang diberikan.
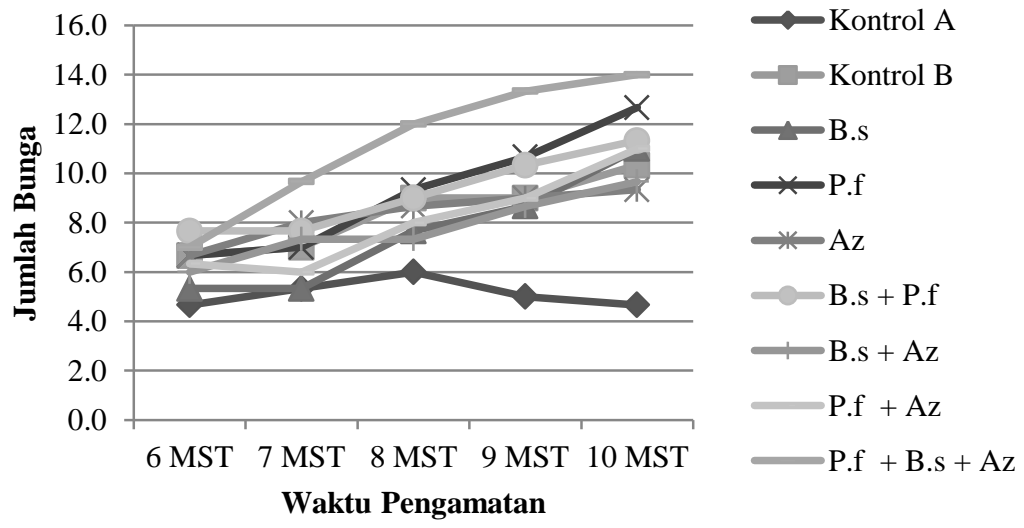

Gambar 4. Grafik Jumlah Bunga Total pada Tanaman Krisan (Kontrol Positif: dengan inokulasi virus, Kontrol Negatif: tanpa inokulasi virus, B.s: B. subtilis, P.f: P. fluorescens, dan Az: Azotobacter sp.)

Berdasarkan hasil analisa statistik dapat diketahui bahwa antar perlakuan kontrol cenderung menunjukkan perbedaan yang nyata. Selanjutnya ketika perlakuan kontrol B dibandingkan dengan perlakuan PGPR menunjukkan hasil yang berbeda nyata secara statistik. Kemudian jika antar pelakuan PGPR dibandingkan, maka hasil yang diperoleh tidak berbeda nyata pada masingmasing perlakuan kecuali pada PGPR tiga kombinasi $P$. fluorescens $+B$. subtilis + Azotobacter sp.

\section{Diameter Bunga}

Pengamatan untuk diameter bunga dilakukan sebanyak tiga kali yaitu pada saat tanaman berusia $10 \mathrm{MST}$ hingga $12 \mathrm{MST}$. Berdasarkan hasil pengamatan dapat diketahui bahwa ukuran diameter bunga krisan sejak pengamatan pertama hingga pengamatan terakhir cenderung meningkat (Gambar 4). Tanaman krisan yang diberi perlakuan PGPR cenderung memiliki diameter bunga yang lebih besar. Berdasarkan hasil tersebut dapat diasumsikan pula bahwa PGPR juga berperan dalam pertumbuhan diameter bunga. 
Agroradix Vol. 3 No.2

ISSN : 2621-0665

Tabel 6. Pengaruh PGPR terhadap Diameter Bunga pada Tanaman Krisan

\begin{tabular}{|c|c|c|c|c|c|c|}
\hline \multirow{2}{*}{ Perlakuan } & \multicolumn{6}{|c|}{ Diameter Bunga $(\mathrm{cm})$, pada umur tanaman MST } \\
\hline & \multicolumn{2}{|c|}{10} & \multicolumn{2}{|c|}{11} & \multicolumn{2}{|c|}{12} \\
\hline Kontrol A & 4,17 & $b$ & 5,47 & $\mathrm{~b}$ & 5,87 & B \\
\hline Kontrol B & 2,74 & a & 3,20 & a & 3,50 & a \\
\hline B. subtilis (B.s) & 4,77 & bc & 5,94 & b & 7,17 & bc \\
\hline P. fluorescens (P.f) & 4,29 & b & 6,57 & $b$ & 7,47 & bc \\
\hline Azotobacter sp. (Az) & 4,57 & bc & 6,57 & b & 7,23 & bc \\
\hline$B . s+P . f$ & 5,41 & bc & 6,36 & $b$ & 8,53 & bc \\
\hline$B . s+A z$ & 4,44 & bc & 6,78 & $b$ & 7,13 & c \\
\hline P.f $+A z$ & 5,14 & bc & 6,27 & $b$ & 7,40 & bc \\
\hline P.f + B.s $+A z$ & 6,03 & c & 7,19 & $b$ & 8,33 & c \\
\hline
\end{tabular}

Keterangan : Pengamatan diameter bunga tanaman krisan dilakukan pada 10-12 Minggu Setelah Tanam (MST).

* Angka yang diikuti dengan huruf yang sama dalam kolom menunjukkan tidak berbeda nyata pada uji Duncan taraf $5 \%$.

* Kontrol A: tanpa PGPR + tanpa inokulasi CMMV, Kontrol B: tanpa PGPR + tanpa inokulasi virus, B.s: B. subtilis, P.f: P. fluorescens, dan Az: Azotobacter sp.

Berdasarkan hasil analisa ragam terhadap dapat diketahui bahwa perlakuan PGPR berpengaruh dalam perningkatan ukuran diameter bunga krisan. Hal ini dapat dilihat pada tabel 10 yang menunjukkan bahwa perlakuan kontrol menunjukkan hasil yang berbeda nyata dengan perlakuan PGPR baik itu perlakuan tunggal maupun kombinasi. Selanjutnya setelah dilakukan perbandingan antar perlakuan, diperoleh hasil yang tidak berbeda nyata baik pada PGPR isolat tunggal maupun PGPR kombinasi.
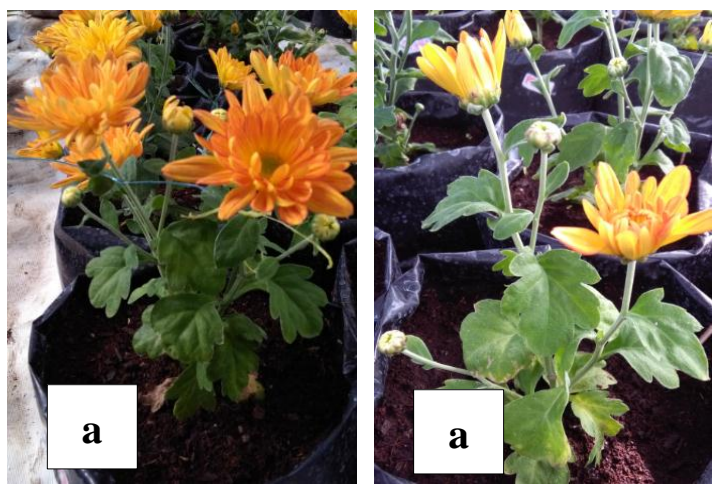

Gambar 5. Perbandingan Bunga Tanaman Krisan. (a. Diberi perlakuan PGPR dan b. Perlakuan kontrol)

\section{Pembahasan Umum}

Berdasarkan hasil penelitian yang telah dilakukan, dapat diketahui bahwa tanaman krisan yang diberi perlakuan PGPR, dapat menunda masa inkubasi CMMV yang menyerang tanaman krisan. Selain menunda masa inkubasi CMMV, PGPR diduga juga mampu menekan intensitas serangan CMMV pada tanaman krisan. Hal ini dikarenakan nilai intensitas pada tanaman yang diberi perlakuan PGPR cenderung lebih kecil jika dibandingkan dengan tanaman yang dijadikan kontrol yaitu tanpa perlakuan PGPR. Hasil yang diperoleh dari pengaruh PGPR terhadap masa inkubasi dan intensitas serangan CMMV pada tanaman krisan tersebut memunculkan asumsi bahwa meskipun kondisi lingkungan mendukung untuk pertumbuhan CMMV dan tanaman inang termasuk kedalam kategori varietas yang rentan terhadap penyakit CMMV, diduga aplikasi agens hayati yaitu PGPR berpengaruh dalam menunda masa inkubasi virus pada tanaman krisan dan menekan intensitas serangan sehingga keparahan penyakit tidak terlalu tinggi. PGPR memiliki sifat sebagai bioprotektan yang mampu melindungi tanaman dari serangan patogen. Baker dan Snyder (1995) menambahkan bahwa mekanisme ketahanan yang diberikan oleh PGPR yaitu dari sifat 
Agroradix Vol. 3 No.2

ISSN : 2621-0665

antagonis yang dimiliki dengan adanya pengeluaran senyawa antibiotik tertentu untuk menekan pertumbuhan patogen.

Terdapat beberapa bakteri yang digunakan sebagai perlakuan untuk mengetahui bagaimana pengaruh masingmasing bakteri tersebut apabila diaplikasikan pada tanaman krisan dalam menekan intensitas serangan penyakit CMMV. Beberapa bakteri yang digunakan sebagai perlakuan terhadap tanaman krisan yaitu $B$. Subtilis, P. fluorescens, dan Azotobacter sp. Bakteri-bakteri tersebut setelah diujijan ternyata memiliki peran masing-masing dalam melindungi tanaman dari serangan patogen.

Bakteri Bacillus sp. tergolong bakteri yang memiliki mekanisme antagonis berupa antibiosis (Abidin dkk., 2015). Spesies Bacillus dapat melindungi tanaman dari patogen melalui beberapa mekanisme, termasuk induksi resistensi sistemik. Lusiyantri (2001) menambahkan bahwa rhizobakteria termasuk Bacillus sp. dapat menginduksi ketahanan fisik dengan cara penebalan dinding sel atau secara kimiawi dengan meningkatkan senyawa fenol dan fitoaleksin yang dapat memberikan ketahanan tanaman terhadap serangan patogen. Penebalan dinding sel pada tanaman menyebabkan patogen terhambat dalam proses penetrasinya ke dalam jaringan tanaman sehingga munculnya gejala awal serangan patogen menjadi lebih lama. Desmawati (2006) juga melaporkan bahwa keberadaan Bacillus sp. dapat menginduksi ketahanan sistemik tanaman terhadap serangan patogen yang selanjutnya akan mempengaruhi masa inkubasi atau munculnya gejala pada tanaman. Bacillus sp. mengendalikan patogen secara tidak langsung yaitu melalui kemampuannya dalam menginduksi ketahanan tanaman.

Bakteri perakaran lain yang diujikan adalah P. fluorescens. Bakteri P. fluorescens diketahui sebagai agens antagonis yang dapat melindungi tanaman dari patogen tanah melalui kompetisi nutrisi dengan cara memproduksi senyawa antimikroba. Hasanudin dkk. (2009) melaporkan bahwa bakteri $P$. flourescens mampu mengendalikan penyakit karat pada krisan dengan senyawa antibiotik yang dihasilkan. $P$. fluorescens mempunyai tipe interaksi dengan patogen berupa pesaing hara, penghasil antibiotika, dan siderofor. Siderofor yang dihasilkan oleh bakteri Pseudomonas yang berfluorescensi dihubungkan dengan kemampuan bakteri tersebut mampu hidup pada kondisi lingkungan $\mathrm{Fe}$ yang terbatas. Siderofor (siderophore) adalah senyawa pengompleks $\mathrm{Fe}^{3+}$ atau penghelat besi spesifik yang dihasilkan oleh beberapa jenis mikroba untuk menyembunyikan unsur besi di lingkungan rhizosfer, sehingga tidak tersedia bagi perkembangan mikroba patogen. Pada kondisi ini bakteri akan memproduksi siderofor diantaranya pioverdin, pioselin, dan asam salisilat. Produksi asam salisilat oleh bakteri Pseudomonas yang berfluorescensi pada rhizofer dapat menimbulkan induksi ketahanan secara sistemik. Asam salisilat merupakan salah satu sinyal transduksi yang berakhir dengan systemic acquired resistance (SAR). Asam salisilat merupakan senyawa penting bagi tanaman berperan dalam proses pertahanan terhadap patogen. Menurut Murphy dkk. (2000) dan Viot dkk. (2009), asam salisilat diketahui merupakan sinyal endogenous pada ketahanan sistemik.

Bakteri lain yang diujikan adalah Azotobacter sp. Sama halnya dengan peran dari bakteri $P$. fluorescens, Azotobacter sp. juga memiliki peran dalam bioprotektan. Rendahnya intensitas serangan CMMV disebabkan karena adanya siderofor yang menyebkan peningkatan ketahanan tanaman terhadap OPT. Siderofor yang dihasilkan memiliki afinitas yang sangat tinggi terhadap besi sehingga akan mengurangi ketersediaan besi di lingkungan dan berdampak pada terhambatnya pertumbuhan patogen tanaman (Duffy dan Defago, 1999).

Bakteri diujikan secara tunggal maupun secara kombinasi. Berdasarkan hasil penelitian diketahui bahwa baik bakteri yang diaplikasikan secara tunggal maupun kombinasi ternyata mampu menekan intensitas serangan CMMV pada tanaman krisan. Hasil penelitian telah menunjukkan bahwa tanaman krisan yang diberi perlakuan PGPR tunggal yaitu Azotobacter sp. saja 
Agroradix Vol. 3 No.2

ISSN : 2621-0665

ternyata mampu memperlambat masa inkubasi dan menekan intensitas serangan CMMV. Hal ini dibuktikan dari perbandingan hasil antara perlakuan kontrol dengan perlakuan PGPR yang tampak berbeda nyata. Namun, tidak menutup kemungkinan jika menginginkan hasil yang lebih baik lagi dalam pengendalian CMMV dapat mengaplikasikan Azotobacter sp. secara kombinasi dengan bakteri lain yaitu $\quad P$. fluorescens atau $B$. subtilis atau dapat pula dengan tiga kombinasi bakteri yaitu $B$. subtilis $+P$. fluorescens + Azotobacter sp.

Hasil yang diberikan dari perlakuan PGPR yang diaplikasikan secara kombinasi tampak lebih baik dibandingkan dengan perlakuan tunggal dikarenakan konsorsium mikroba dapat menghasilkan beberapa jenis antibiotik yang berbeda-beda. Jenis antibiotik lebih dari satu jenis diduga mampu memiliki kemampuan lebih signifikan dalam menekan pertumbuhan penyakit CMMV bandingkan dengan jenis perlakuan lainnya. Hal ini didukung oleh pernyataan Raupach dan Klopper (1998) yang menyatakan bahwa konsorsium mikroba memiliki penekanan terhadap penyakit lebih baik dan lebih konsisten dalam penekanan penyakit tanaman dibandingkan dengan penggunaan agens hayati secara tunggal. Konsorsium mikroba juga dapat memperluas spektrum sebagai agens pengendali hayati, karena keberadaannya yang beragam memiliki kedekatan dengan kondisi alam yang memiliki konsep keberagaman.

Jenis penginduksian yang ditunjukkan oleh PGPR adalah Induced Systemic Resistance (ISR). Mekanisme ini terjadi sebagai akibat dari infeksi patogen sehingga tanaman memberikan respon berupa reaksi-reaksi pertahanan seperti HR yang menyebabkan terjadinya lesion nekrotik pada daerah terserang. Beberapa faktor yang dapat mempengaruhi ISR adalah senyawa kimia (siderofor, antibiotik, dan ion $\mathrm{Fe}$ ) yang dihasilkan rizobakteria dan komponen sel bakteri (dinding sel mikroba, flagella, filli, membran lipopolisakarida (LPS)) dapat sebagai elicitor dalam menginduksi ketahanan secara sistemik (Erbs and Newman, 2003).
Selain pengujian PGPR terhadap intensitas serangan CMMV pada tanaman krisan, pada penelitian ini juga dilakukan pengujian PGPR terhadap pertumbuhan dan produksi pada tanaman krisan. Hasil pengamatan menunjukkan pengaruh yang berbeda nyata antara perlakuan kontrol dengan tanaman yang diberi perlakuan PGPR baik itu terhadap pertumbuhan maupun produksi tanaman. Berdasarkan hasil tersebut dapat diasumsikan bahwa PGPR memiliki pengaruh yang nyata terhadap pertumbuhan dan produksi tanaman krisan. Konsentrasi SA dalam tanaman mampu menentukan aktivasi gen ketahanan dalam tanaman.

Indikator pertumbuhan yang diamati pada penelitian ini adalah tinggi tanaman dan jumlah daun. Berdasarkan hasil pengamatan mengenai pengaruh PGPR terhadap tinggi tanaman dan jumlah daun diperoleh hasil bahwa tanaman yang diberi perlakuan PGPR baik secara tunggal maupun kombinasi memberikan hasil yang lebih tinggi dibandingkan perlakuan kontrol. Sama halnya pada pengamatan terhadap intensitas serangan penyakit, PGPR kombinasi memberikan hasil yang lebih baik dibandingkan PGPR tunggal. PGPR kombinasi yang terdiri dari bakteri $B$. Subtilis, $P$. fluorescens, dan Azotobacter sp. mampu memacu partumbuhan tinggi tanaman dan jumlah daun.

PGPR yang digunakan dalam penelitian tersebut ternyata memiliki peran penting dalam pertumbuhan tanaman. Berdasarkan penyataan Wardanah (2007) yang menyatakan bahwa hormon pertumbuhan yang dihasilkan oleh PGPR adalah giberellin, auksin, dan sitokinin sehingga tanaman yang diberi PGPR umumnya memiliki pertumbuhan yang lebih baik. Tjondronegoro, dkk (1989) menambahkan bahwa PGPR mampu meningkatkan pertumbuhan tanaman secara langsung melalui hormon-hormon pertumbuhan yang dihasilkan seperti Giberelin (Gac) dan indole 3-acetic acid (IAA). IAA merupakan hormon pertumbuhan kelompok auksin yang berguna untuk merangsang pertumbuhan tanaman. Auksin 
Agroradix Vol. 3 No.2

ISSN : 2621-0665

berguna untuk meningkatkan pertumbuhan sel batang, menghambat proses pengguguran daun, merangsang pembentukan buah, merangsang pertumbuhan kambium, dan menghambat pertumbuhan tunas ketiak. Hormon pertumbuhan ini mampu merangsang pertumbuhan akar lateral.

Ketiga bakteri yang digunakan dalam penelitian memiliki peran masing-masing dalam pertumbuhan tanaman. Bakteri $B$. subtilis dan $P$. fluorescens memiliki peran yang sama dalam memacu pertumbuhan tanaman. Kedua bakteri ini mampu menghasilkan hormon auksin, giberelin, dan sitokinin yang dapat memacu pertumbuhan. Selanjutnya Bustamam (2006) menambahkan pula bahwa Bacillus sp. dapat membantu dekomposisi bahan organik dalam tanah sehingga dihasilkan nutrisi untuk meningkatkan pertumbuhan tanaman. Bacillus sp. juga memiliki kemampuan sebagai pelarut fosfat sehingga menyebabkan unsur fosfat lebih tersedia untuk diserap oleh tanaman sehingga pertumbuhan tanaman menjadi optimal. Mikroba pelarut fosfat bersifat menguntungkan karena mengeluarkan berbagai macam asam organik seperti asam format, asetat, propional, laktat, glikolat, fumarat, dan suksinat. Asam-asam organik ini dapat membentuk khelat organik dengan kation $\mathrm{Al}, \mathrm{Fe}$, atau $\mathrm{Ca}$ yang mengikat $\mathrm{P}$ sehingga ion $\mathrm{H}_{2} \mathrm{PO}_{4}{ }^{2-}$, menjadi bebas dari ikatannya dan tersedia bagi tanaman untuk diserap.

Selain itu, bakteri lain yang digunakan adalah Azotobacter sp. Bakteri ini dilaporkan juga mampu menghasilkan hormon auksin (Kholoda dan Zulaika, 2015). Azotobacter sp. berfungsi untuk melindungi atau menyelimuti hormon tumbuhan dan juga berfungsi sebagai mikroba penambat $\mathrm{N}$ dari udara bebas. Pemanfaatan bakteri fiksasi $\mathrm{N}_{2}$ mampu meningkatkan efisiensi pemupukan $\mathrm{N}$. Azotobacter sp. merupakan bakteri fiksasi $\mathrm{N}$ yang mampu menghasilkan substansi zat pemacu tumbuh giberelin, sitokinin, dan asam indol asetat, sehingga dapat memacu pertumbuhan akar. Selain itu juga dapat mempercepat perkecambahan bila diaplikasikan pada benih dan merangsang regenerasi bulu-bulu akar sehingga penyerapan unsur hara melalui akar menjadi optimal (Alexander, 1977).

Hasil penelitian mengenai pengaruh PGPR terhadap produksi tanaman krisan diperoleh bahwa tanaman krisan yang diberi perlakuan PGPR memiliki hasil yang lebih baik pada waktu muncul primordia bunga, jumlah bunga total, dan diameter bunga. Hal ini dikarenakan PGPR mampu menghasilkan hormon giberelin yang berfungsi dalam hal merangsang pembungaan. Giberelin dapat berpengaruh terhadap pemanjangan batang, pembungaan, dan pembuahan. Kusumo (1984) menambahkan jika giberelin mampu mempengaruhi pembesaran sel (peningkatan ukuran) dan mempengaruhi pembelahan sel (peningkatan jumlah). Pertambahan ukuran sel menghasilkan pertambahan ukuran jaringan, organ dan akhirnya meningkatkan ukuran tubuh tanaman secara keseluruhan.

Penelitian terdahulu menyebutkan bahwa pada tanaman hari panjang yang tidak dapat berbunga pada hari pendek, dapat dirangsang pembungaannya dengan menggunakan giberelin (Kusumo, 1984). Penelitian tersebut dapat diterapkan pada tanaman krisan yang diujikan karena tanaman krisan merupakan salah satu jenis tanaman hari panjang. Tanaman yang diberi perlakuan $P$. fluorescens secara tunggal maupun kombinasi dengan bakteri lain terbukti lebih baik dalam produksinya. Hal ini dikarenakan bakteri tersebut mampu memproduksi fitohormon, yaitu auksin, sitokinin, giberelin, etilen dan asam absisat. Beberapa karakter penting dari rizobakteri Pseudomonas dalam meningkatkan pertumbuhan tanaman adalah menghasilkan hormon tumbuh seperti IAA, giberelin, memfiksasi, dan melarutkan $P$. Hormon auksin akan bekerja secara sinergis dengan dua hormon lain, yaitu sitokinin dan giberelin sehingga ketika bakteri tunggal yang mampu menghasilkan giberelin akan memberikan hasil produksi yang lebih baik ketika dikombinasikan dengan bakteri lain yang mampu menghasilkan sitokinin dan auksin.

Berdasarkan hasil penelitian diketahui bahwa pengaplikasian PGPR isolat tunggal 
Agroradix Vol. 3 No.2

ISSN : 2621-0665

telah mampu meningkatkan pertumbuhan tanaman krisan yaitu tinggi tanaman dan jumlah daun. Misalnya saja pada perlakuan PGPR isolat tunggal $P$. fluorescens yang secara umum mampu meningkatkan pertumbuhan dan produksi tanaman krisan. Hasil penelitian menunjukkan setelah dibandingkan dengan perlakuan kontrol diketahui bahwa dengan pemberian $P$. fluorescens secara tunggal memberikan pengaruh yang nyata terhadap pertumbuhan dan produksi dari tanaman krisan. Namun, apabila menginginkan hasil yang lebih baik lagi dapat pula dikombinasikan dengan bakteri lain misalnya $P$. fluorescens yang dikombinasikan dengan $B$. subtilis atau Azotobacter sp.atau juga dapat dikombinasikan menjadi tiga kombinasi yaitu $P$. fluorescens $+B$. subtilis + Azotobacter sp.

\section{KESIMPULAN}

Perlakuan PGPR tunggal maupun kombinasi mampu menunda masa inkubasi, menekan intensitas serangan CMMV, meningkatkan pertumbuhan, dan produksi pada tanaman krisan lebih baik dibandingkan perlakuan tanpa PGPR.

\section{DAFTAR PUSTAKA}

Abidin, Z., L. Q. Aini., dan A. L. Abadi. 2015. Pengaruh Bakteri Bacillus sp. dan Pseudomonas sp. Terhadap Pertumbuhan Jamur Patogen Sclerotium rolfsii Sacc. Penyebab Penyakit Rebah Semai Pada Tanaman Kedelai. J. HPT. 3(1):1-10.

Agrios, G. N. 2005. Plant Pathology. Fifth Edition. Academic Press. New York. 922 p.

Alexander, M. 1977. Introduction to Soil Mycrobiology. $2^{\text {nd }}$ Ed. John Wiley and Sons. New York. 467 p.

Baker, K. F. dan W. C Snyder. 1965. Ecology of Soil-Borne Plant Pathogens: Prelude to Biological Control. University of California Press. Berkeley.
Boss, L. 1990. Pengantar virologi tumbuhan, Gadjah Mada Press, Yogyakarta, 226 hlm.

Bustamam, H. 2006. Seleksi Mikroba Rizosfer Antagonis terhadap Bakteri Ralstonia solanacearum Penyebab Penyakit Layu Bakteri pada Tanaman Jahe di Lahan Tertindas. Jurnal Ilmu-Ilmu Pertanian Indonesia 8 (1):12-18.

Choliq, F.A., Martosudiro, M., Apriliana, Q.A., Istiqomah, I., 2019. Pengaruh Pemberian Urin Kelinci Terhadap Serangan Turnip Mosaic Virus (TuMV) Pada Tanaman Kailan (Brassica oleraceae var. alboglabra) yang Dibudidayakan Secara Organik. AGRORADIX J. IImu Pertan. 2, 18-31.

Duffy, B.K., dan G. Défago. 1999. Environmental factors modulating antibiotic and siderophore biosynthesis by Pseudomonas fluorescens biocontrol strains. Applied and Environmental Microbiology 65: 2429-2438.

Ekanantari. 2014. Outlook Komoditi Krisan.Jakarta. Pusat Data dan Sistem Informasi Pertanian. Kementrian Pertanian. $6 \mathrm{hlm}$.

Erbs, G. dan M. A Newman. 2003, The role of lipopolysacharides in induction of plant defence responses. Mol. Plant Pathol. 4:421-425.

Habazar, T. dan Yaherwandi. 2006. Pengendalian Hayati Hama dan Penyakit Tumbuhan. Andalas University Press. Padang. $390 \mathrm{hlm}$.

Hasanudin, W.N., E. Silvia, I. Djatnika, dan B. Marwoto. 2010. Formulasi Biopestisida Berbahan Aktif Bacillus subtilis, Pseudomonas fluorescens, dan Corynebacterium Non Patogenik Untuk Mengendalikan Penyakit Karat Pada Krisan. J. Hort. 20(3):247-261.

Kennedy, J. S., M. F. Day, dan V. F. Eastop. 1962. A Conspectus of Aphids as Vectors of Plant Viruses. Comm. Inst. Ent., London. 428 p. 
Kholida, F. T., dan E. Zulaika. 2015. Potensi Azotobactersebagai Penghasil Hormon IAA (Indole-3-Acetic Acid). Jurnal Sains Dan Seni ITS. 4(1):2337-3520.

Kusumo, S. 1984. Zat Pengatur Tumbuh Tanaman. Jakarta. CV. Yasaguna.

Lusiyantri, N. 2011. Uji pengimbasan ketahanan dengan Bacillus sp. dan kultur filtratnya terhadap serangan jamur Ganoderma boninense dan pertumbuhan bibit kelapa sawit di pembibitan awal. Skripsi Fakultas Pertanian Universitas Riau. Pekanbaru.

Murphy, J. F., G. W. Zehnder, D. J. Schuster, E. J. Sikora, J. E. Polston, dan J. W. Kloepper. 2000. Plant growthpromoting rhizobacterial mediated protection in tomato against tomato mottle virus. Plant Dis. 84:779-784.

Nurmas, A., R. Nofianti, Abdul, dan K. Andi. 2014. Eksplorasi dan Karakterisasi Azotobacter indigenous untuk Pengembangan Pupuk Hayati Tanaman Padi Gogo Lokal di Lahan Marjinal. Jurnal Agroteknos. 4(2).127-133.

Panagan, A. T. 2011. Isolasi Mikroba Penghasil Antibiotika dari Tanah Kampus Unsri Indralaya Menggunakan Media Ekstrak Tanah. Jurnal Penelitian Sains. 4(3):143148.

Rahni, N. M. 2012. Efek Fitohormon PGPR Terhadap Pertumbuhan Tanaman Jagung (Zea Mays). Jurnal Agribisnis dan Pengembangan Wilayah. 3(2):4-8.

Raupach, G. S. dan J. W. Kloepper. 1998. Mixtures of Plant Growth Promoting Rhizobacteria Enhance Biological
Control of Multiple Cucumber Pathogens. Phytopathology. 88:11581164.

Salamiah dan R. Wahdah. 2015. Pemanfaatan Plant Growth Promoting Rhizobacteria (PGPR) dalam pengendalian penyakit tungro pada padi lokal Kalimantan Selatan. Pros Sem Nas Masy Biodiv Indon1 (6): 1448- 1456.

Sastrahidayat, I. R. 2011. Penyakit Tanaman Sayur-sayuran. UB Press. Malang.

Suryanto, A., Kuswanto., S. M. Sitompul, dan A. Kasno. 2015. Heritability estimation in resistant soybean towards cowpea mild mottle virus (CPMMV). International Journal of Biosciences. ISSN: 2220-6655. 6(6):29-36.

Tjondronegoro, P. D., M. Natasaputra, A. W. Gumawan, M. Djaelani, dan A. Suwanto. 1989. Botani Umum. PAU IImu Hayati Institut Pertanian Bogor, Bogor. $581 \mathrm{hlm}$.

Untung,K. 1993. Pengantar Pengelolaan Hama Terpadu, Gajah Mada University Press. Yoyakarta. $273 \mathrm{hlm}$.

Vlot, A. C., D. A. Dempsey, dan D. F. Klessig. 2009. Salicylic acid, a multifacated hormone to combat disease. Jurnal Phytopathology. 47:177 - 206.

Wardanah, T. 2007. Pemanfaatan bakteri perakaran pemacu pertumbuhan tanaman (Plant Growth-Promoting Rhizobacteria) untuk mengendalikan penyakit mosaik tembakau (Tobacco Mosaic Virus) pada tanaman cabai. Skripsi. Fakultas Pertanian Institut Pertanian Bogor. 